\title{
Isolasi dan identifikasi bakteri dari susu kambing peranakan Ettawa (PE) terjangkit mastitis subklinis di Kemiri Kebo, Sleman, Yogyakarta
}

\section{Isolation and identification of bacteria from goat milks subclinical mastitis Ettawa crossbreed goat (PE) in Kemiri Kebo, Sleman, Yogyakarta}

\author{
Widodo Suwito ${ }^{1}{ }^{*}$ Andriani $^{2}$, dan Widagdo Sri Nugroho ${ }^{3}$ \\ ${ }^{1}$ Balai Pengkajian Teknologi Pertanian Yogyakarta \\ J1. Stadion Baru Maguwoharjo 22 \\ Karang Sari, Wedomartani, Ngemplak, Sleman, Yogyakarta \\ ${ }^{2}$ Balai Besar Penelitian Veteriner \\ Jl. R.E. Martadinata 30, Bogor 16124 \\ ${ }^{3}$ Laboratorium Kesehatan Masyarakat Veteriner \\ Fakultas Kedokteran Hewan, Universitas Gadjah Mada, Jl Fauna no 2, Yogyakarta 55281
}

Submitted: 18 Desember 2018, Accepted: 19 Maret 2019

\begin{abstract}
ABSTRAK: Mastitis subklinis pada kambing peranakan Ettawa (PE) merupakan penyakit yang merugikan secara ekonomi karena menurunkan produksi susu yang disebabkan oleh bakteri. Tujuan penelitian ini untuk mengisolasi bakteri penyebab mastitis subklinis pada kambing PE di Kemiri Kebo, Turi, Sleman, Yogyakarta. Sebanyak 24 sampel susu kambing mastitis subklinis digunakan dalam penelitian ini. Penentuan status mastitis subklinis pada kambing PE dengan uji CMT positif (++) atau $(+++)$. Isolasi dan identifikasi bakteri secara konvensional berdasarkan reaksi biokimia. Mastitis subklinis pada kambing PE di Kemiri Kebo, Turi, Sleman, Yogyakarta disebabkan oleh Staphylococcus intermedius (38\%), Staphylococcus aureus (32\%), Staphylococcus epidermidis (25\%), Staphylococcus hycus (12\%), Streptococcus sp (22\%), Corynebacterium sp (12\%), Pseudomonas aeruginosa (18\%), dan Escherichia coli (2\%). Penelitian ini menunjukkan bahwa bakteri Gram positif lebih dominan sebagai penyebab mastitis subklinis pada kambing PE daripada Gram negatif.
\end{abstract}

Kata kunci : bakteri; kambing PE; mastitis subklinis.

ABSTRACT: Subclinical mastitis in Ettawa crosbreed goat (PE) is economic disease which lost milk yield that bacteria caused. The aim of these research was to isolatian and identification bacteria that caused subclinical mastitis in PE goat from Kemiri Kebo, Turi, Sleman, Yogyakarta. A total of 24 goat milk PE subclinical mastitis samples, were used in these research. Determination of subclinical mastitis in PE goat used CMT test which $(++)$ and $(+++)$ results. Isolation and identification conventional bacteria based on biochemical. Subclinical mastitis PE goat in Kemiri Kebo, Turi, Sleman, Yogyakarta was caused Staphylococcus intermedius (38\%), Staphylococcus aureus (32\%), Staphylococcus epidermidis (25\%), Staphylococcus hycus (12\%), Streptococcus sp (22\%), Corynebacterium sp (12\%), Pseudomonas aeruginosa (18\%), and E. coli (2\%). The research showed that Gram positive bacteria is dominant that caused subclinical mastitis in PE goat compared than Gram negative bacteria.

Keywords : bacteria; PE goat; subclinical mastitis.

"Corresponding Author: widodo.suwito@yahoo.com 


\section{PENDAHULUAN}

Kambing peranakan Ettawa (PE) merupakan salah satu jenis kambing penghasil susu kambing yang banyak dipelihara di Turi, Sleman, Yogyakarta. Produksi susu kambing yang masih terbatas serta belum banyak yang membudidayakannya menyebabkan harga susu kambing lebih mahal dibandingkan dengan susu sapi. Selain hal tersebut, susu kambing di masyarakat banyak yang menggunakan sebagai obat sakit pernafasan serta dapat menambah vitalitas. Hal tersebut kemungkinan karena kandungan nutrisi yang jauh lebih komplit dibandingkan susu sapi atau yang lainnya. Sementara itu, Tomita et al. (1991) menyatakan bahwa komponen peptida dari laktoferin dalam susu kambing dapat berfungsi sebagai antibiotika sehingga dapat digunakan untuk mengatasi penyakit infeksi saluran pernafasan.

Mastitis subklinis pada kambing PE merupakan penyakit yang dapat merugikan secara ekonomi karena produksi susu menjadi berkurang bahkan sampai berhenti. Penurunan produksi susu kambing karena mastitis subklinis sekitar $37 \%$ hingga $60 \%$ (Fthenakis and Jones, 1990; Koop et al., 2010). Sementara itu, peternakan kambing dengan prevalensi mastitis subklinis 30\% dapat menyebabkan kerugian karena penurunan produksi susu sekitar 36 euro per laktasi (Contreras et al., 2003).

Masalah yang di jumpai pada peternak kambing PE yaitu mastitis subklinis yang hingga kini belum dikenali oleh peternak kambing PE karena tidak menunjukan gejala yang jelas. Sebaliknya, peternak kambing PE lebih mengenal mastitis klinis dengan istilah ngrangkaki yang biasa terjadi setelah melahirkan. Mastitis subklinis apabila dibiarkan berlarut-larut produksi susu menjadi turun bahkan dapat berhenti. Sementara itu, mastitis subklinis hanya dapat diketahui melalui uji california mastitis test (CMT), sedangkan tanpa uji CMT mastitis subklinis pada kambing PE tidak dapat dikenali. Kambing dikatakan mastitis subklinis apabila dengan uji CMT menunjukkan hasil positif $2(++)$ atau positif $3(+++)$, yang selanjutnya diikuti dengan pemeriksaan bakteri patogen (McDougall et al., 2002 ; Persson and Olofsson, 2011).

Kambing PE di Kemiri Kebo, Turi, Sleman, Yogyakarta adalah milik peternakan rakyat yang cara pemeliharaan dan pemerahannya masih dikerjakan secara tradisional sehingga mastitis subklinis merupakan ancaman yang patut diperhatikan. Pemerahan dengan tangan dan kondisi lantai kandang yang kotor dapat berperan sebagai sumber bakteri yang dapat menginfeksi ambing, karena pada saat diperah otot spinter dari putting dalam keadaan membuka dan biasanya kambing PE setelah diperah akan rebahan di lantai kandang. Selain hal tersebut, jenis air yang digunakan untuk mencuci ambing sebelum pemerahan dapat sebagai sumber bakteri. Penelitian Suwito et al. (2013) menunjukkan bahwa air yang digunakan untuk mencuci ambing dapat sebagai sumber Pseudomonas aeruginosa. Sementara itu, pemerahan yang masih dilakukan dengan tangan dapat sebagai sumber Staphylococcus spp. Tangan pemerah sebagai sumber Staphylococcus aureus. (Muda et al., 2011). Selain hal tersebut, peternak kambing PE yang mencuci ambing dengan air sumur dapat terkontaminasi Pseudomonas aeruginosa. Oleh karena itu, tujuan dari penelitian ini adalah isolasi dan identifikasi bakteri pada susu kambing PE yang mengalami mastitis subklinis.

\section{MATERI DAN METODE Materi Penelitian}

Sebanyak 24 sampel susu kambing PE terjangkit mastitis subklinis dari 57 ekor kambing PE yang sedang laktasi digunakan sebagai materi dalam penelitian ini. 


\section{Koleksi Sampel}

Koleksi sampel dilakukan pagi hari mengikuti petunjuk Hall and Rycroft (2007). Kambing PE diposisikan dalam keadaan berdiri, kemudian putting dibersihkan dengan alkohol 70\%. Sebanyak kurang lebih $20 \mathrm{ml}$ susu kambing ditampung dalam botol plastik steril dan segera dimasukan ice box untuk dibawa ke laboratorium untuk diproses lebih lanjut.

\section{Status Mastitis Subklinis}

Status mastitis subklinis pada kambing PE ditentukan dengan uji CMT. Uji CMT dilakukan dengan mencampur reagen CMT dengan susu dari masing-masing putting kambing dengan perbandingan yang sama. Campuran digerakan perlahan-lahan, dan hasil uji CMT dikatakan positif apabila muncul massa yang mengental. Hasil uji CMT dikelompokkan menjadi positif $1(+)$ ditandai dengan timbulnya massa yang sedikit mengental, positif $2(++)$ ditandai dengan terbentuknya massa yang mengental, dan positip $3(+++)$ ditandai dengan terbentuknya massa yang menyerupai gelatin, dan sulit digerakkan. Kambing PE dikatakan mastitis subklinis apabila uji CMT menunjukkan positif 2 (++) sampai positif $3(+++)$, kemudian dilanjutkan dengan pemeriksaan mikrobiologik (Persson and Olofsson, 2011; McDougall et al., 2002).

\section{Isolasi dan identifikasi bakteri}

Isolasi dan identifikasi bakteri dari susu kambing PE mastitis dilakukan dengan menambahkan $25 \mathrm{ml}$ larutan buffer peptone water (BPW) (Oxoid Ltd., Basingstoke, United Kingdom) kedalam $5 \mathrm{ml}$ susu kambing PE mastitis subklinis yang selanjutnya di inkubasikan pada suhu $37^{\circ} \mathrm{C}$ selama 24 jam. Subkultur dalam media mannitol salt agar (MSA) (Oxoid Ltd., Basingstoke, United Kingdom), nutrient agar (NA) (Oxoid Ltd., Basingstoke, United Kingdom), macConkey agar (McA) (Oxoid Ltd., Basingstoke, United Kingdom), dan eosin methylene blue agar (EMBA) (Oxoid Ltd., Basingstoke, United Kingdom) yang selanjutnya diinkubasikan pada suhu $37^{\circ} \mathrm{C}$ selama 24 jam. Koloni yang tumbuh dalam media MSA, NA, McA, dan EMB dilakukan pewarnaan Gram, dan selanjutnya di uji biokimia seperti katalase, oksidase, Mr-Vp, dan uji kemapuan fermentasi terhadap gula-gula lainnya (Tong et al., 2015). Hasil isolasi dan identifikasi bakteri dianalisis secara deskriptif.

\section{HASIL DAN PEMBAHASAN}

Isolasi dan identifikasi bakteri dapat dikerjakan secara konvensional berdasarkan reaksi biokimia. Pewarnaan Gram diperlukan untuk mengetahui morfologi bakteri dan mengklasifikasikan bakteri Gram positif atau negatif. Hasil pewarnaan Gram bakteri (Gambar 1).

Berdasarkan pewarnaan Gram, morfologi Staphylococcus spp., berbentuk coccus, bergerombol, dan termasuk Gram positif (Gambar 1). Tong et al. (2015) menyatakan bahwa Staphylococcus spp., merupakan bakteri Gram positif, bersifat fakultatif an aerob, tidak menghasilkan spora, tidak bergerak, katalase positif, oksidase negatif, berbentuk coccus dan banyak terdapat pada permukaan kulit manusia maupun hewan. Staphylococcus spp., memiliki dua sifat yaitu memfermentasi mannitol atau tidak memfermentasi mannitol dalam waktu 24 jam. 


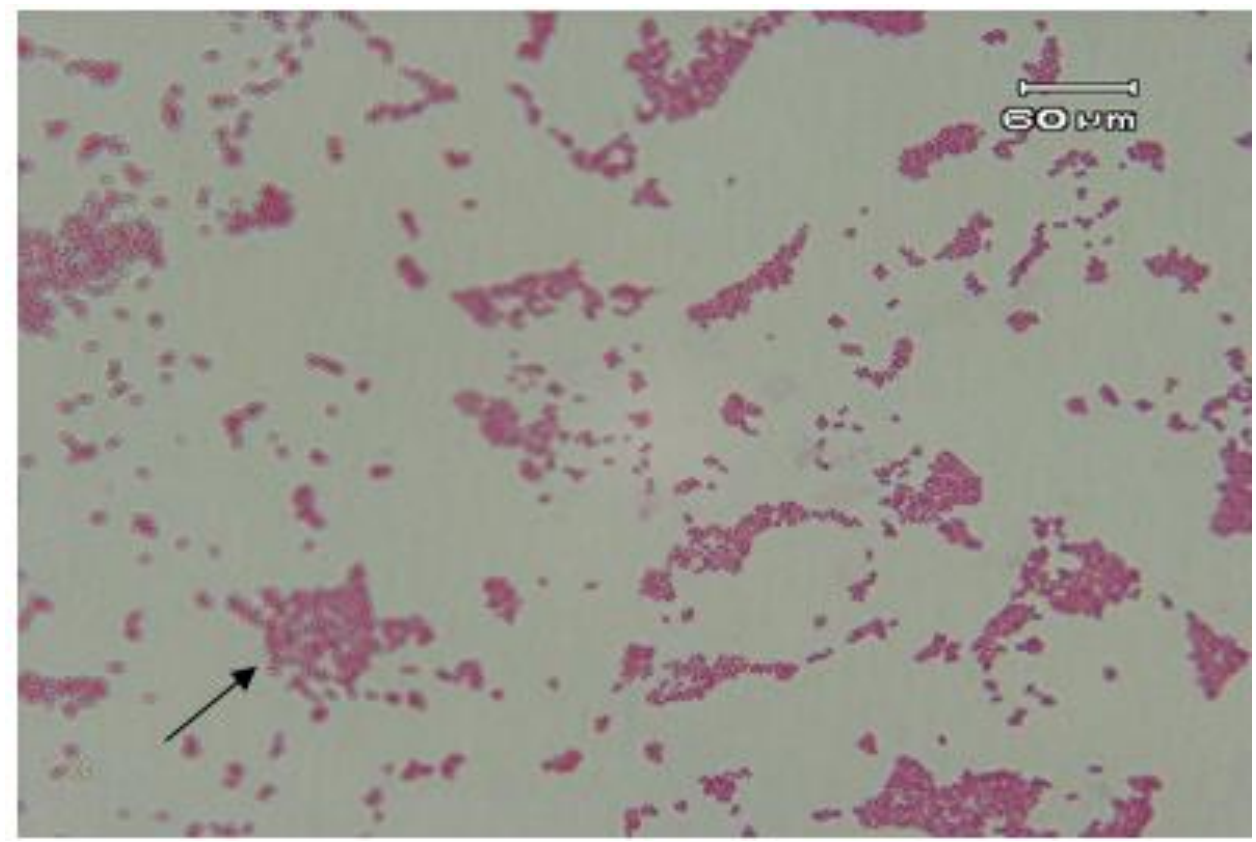

Gambar 1. Staphylococcus spp.,umur 24 jam pewarnaan Gram perbesaran 100x Staphylococcus spp., tampak coccus bergerombol

Kemampuan Staphylococcus spp., fermentasi mannitol berwarna merah. dalam memfermentasi mannitol Beberapa koloni bakteri yang berhasil ditunjukkan dengan warna koloni menjadi diisolasi dari susu kambing PE mastitis kuning, sedangkan yang tidak mem- subklinis (Gambar 2).
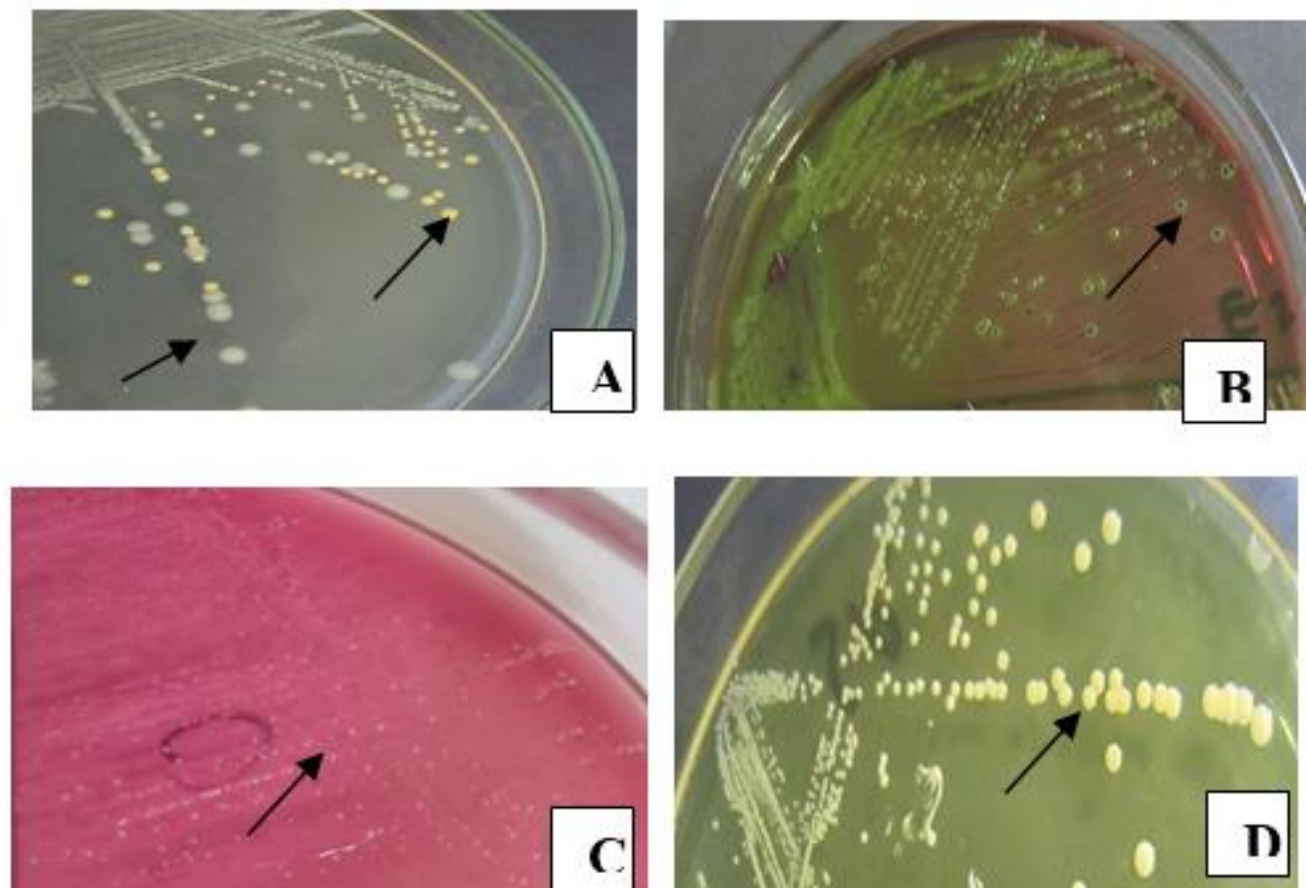

Gambar 2. Koloni bakteri (A) Staphylococcus spp., warna kuning dan Pseudomonas spp., abu-abu pada media NA; (B) Escherichia coli warna hijau metalik pada media EMBA; (C) Staphylococcus spp., warna merah tidak memfermentasi mannitol pada media MSA; dan (D) Staphylococcus spp., warna kuning memfermentasi mannitol pada media MSA 
Media NA merupakan media umum bakteri sehingga bakteri Gram positif maupun negatif mampu tumbuh. Koloni bakteri yang berwarna kuning diduga Staphylococcus spp., sedangkan koloni yang berwarna kehijauan kemungkinan Pseudomonas spp. Sementara itu, Escherichia coli merupakan bakteri Gram negatif yang dalam media EMBA tampak hijau metalik. Koloni Staphylococcus spp., yang memfermentasi mannitol berwarna kuning, sedangkan yang tidak memfermentasi mannitol berwarna merah (Gambar 2). Hasil isolasi dan identifikasi bakteri dari susu kambing PE mastitis subklinis (Tabel 1).

Tabel 1. Isolasi dan identifikasi bakteri dari susu kambing PE mastitis subklinis

\begin{tabular}{ll}
\hline Jumlah sampel $(\mathrm{n}=24)$ & Jenis bakteri $(\%)$ \\
\hline Staphylococcus intermedius & 38 \\
Staphylococcus aureus & 32 \\
Staphylococcus epidermidis & 25 \\
Staphylococcus hycus & 12 \\
Streptococcus sp & 22 \\
Pseudomonas aeruginosa & 18 \\
Corynebacterium sp & 12 \\
Escherichia coli & 2 \\
\hline
\end{tabular}

Mastitis subklinis pada kambing PE di Kemiri Kebo, Turi, Sleman disebabkan oleh beberapa bakteri yaitu Staphylococcus intermedius, Staphylococcus aureus, Staphylococcus epidermidis, Staphylococcus hycus, Streptococcus sp, Corynebacterium sp, Pseudomonas aeruginosa, dan Escherichia coli. Berdasarkan Tabel 1, maka Staphylococcus intermedius paling banyak sebagai penyebab terjadinya mastitis subklinis pada kambing PE yaitu sejumlah 38\%. Hasil penelitian yang sama juga dilaporkan oleh Contreras et al. (2007) bahwa Staphylococcus intermedius pada kambing mastitis subklinis sebesar 36,4\%. Sementara itu, hasil penelitian yang berbeda di laporkan oleh Sanchez et al. (1999) bahwa kambing penderita mastitis subklinis tidak ditemukan Staphylococcus intermedius. Perbedaan hasil penelitian tersebut kemungkinan disebabkan oleh banyak faktor. Faktor manajemen peternakan kambing dapat menyebabkan perbedaan tingkat kejadian mastitis subklinis. Faktor-faktor yang dapat sebagai pemicu terjadinya mastitis subklinis pada kambing antara lain produksi susu, umur saat laktasi, umur penyapihan, dan body condition score (BCS) (Suwito et al., 2013).

Staphylococcus aureus merupakan penyebab mastitis subklinis pada kambing PE yang kedua setelah Staphylococcus intermedius yaitu sebesar 32\% (Tabel 1). Hasil penelitian tersebut hampir sama dengan Arsenault et al. (2008) bahwa prevalensi Staphylococcus aureus koagulase negatif penyebab mastitis subklinis di Canada sebesar 17\%. Staphylococcus aureus dilaporkan sebagai penyebab mastitis subklinis pada kambing sekitar $11 \%$ dan paling banyak bersifat koagulase negatif (Contreras et al., 2007 ; Moroni et al., 2005). Prevalensi Staphylococcus aureus penyebab mastitis subklinis pada kambing paling besar terjadi di Inggris yang mencapai 40\% (Hall and Rycroft, 2007). Mastitis subklinis pada kambing yang diperah dengan mesin pemerah prevalensi Staphylococcus aureus 6\% (Contreras et al., 1995). Sementara itu, di Kemiri Kebo, Sleman, pemerahannya menggunakan tangan sehingga berisiko 
menyebabkan mastitis subklinis karena Staphylococcus aureus. Hal tersebut kemungkinan karena tangan pemerah sebagai sumber Staphylococcus aureus. Tangan pemerah berpotensi sebagai perantara penularan Staphylococcus aureus dari ambing satu ke ambing lainnya (Muda et al., 2011). Oleh karena itu, sebelum pemerahan berlangsung sebaiknya pemerah mencuci tangan dengan sabun atau desinfektan. Selain tangan pemerah, Staphylococcus aureus juga berasal dari kulit di sekitar ambing, kain yang digunakan untuk mengeringkan ambing, mesin pemerah, dan lingkungan sekitar kandang. Sutra and Poutrel (1994) menyatakan bahwa pemerahan yang dilakukan oleh orang yang berbeda-beda berpeluang lebih besar terjadi mastitis subklinis karena Staphylococcus aureus.

Staphylococcus epidermidis pada kambing PE mastitis subklinis 25\% (Tabel 1). Hasil tersebut lebih tinggi dibandingkan dengan penelitian Contreras et al. (1995) sebesar 20\%. Sementara itu, Bergonier et al. (2003) menyatakan bahwa Staphylococcus epidermidis koagulase negatif merupakan penyebab mastitis subklinis yang paling banyak dibandingkan yang lainnya. Perbedaan hasil penelitian tersebut kemungkinan disebabkan oleh beberapa faktor seperti manajemen pemerahan, jenis kambing, serta iklim.

Staphylococcus hycus merupakan bakteri berbentuk coccus yang paling sedikit menyebabkan mastitis subklinis pada kambing PE dibandingkan Staphylococcus spp., lainnya (Tabel 1). Beberapa peneliti menyatakan bahwa Staphylococcus hycus hanya sedikit menyebabkan mastitis subklinis pada kambing dan kurang patogen di bandingkan Staphylococcus spp., koagulase negatif lainnya. Penelitian Andresen (2005) menunjukkan bahwa Staphylococcus hyicus yang diisolasi dari babi penderita epidermidis eksudatif termasuk patogen karena menghasilkan ekfoliatif toksin dan menyebabkan mastitis pada sapi di Jepang. Staphylococcus hyicus dibagi menjadi dua kelompok yaitu patogen dan tidak patogen. Eksudatif epidermitis merupakan penyakit kulit pada babi yang disebabkan oleh Staphylococcus hyicus yang bersifat patogen (Wegener, Andresen, and Hansen, 1993).

Streptococcus sp., kelompok bakteri Gram positif penyebab mastitis subklinis pada kambing PE di Kemiri Kebo, Turi, Sleman sebesar 22\% (Tabel 1). Mastitis subklinis pada kambing PE karena Streptococcus sp., lebih cepat terlihat dalam penurunan produksi susu dibandingkan dengan bakteri lainnya. Suwito et al. (2018) melaporkan bahwa mastitis subklinis kronis pada kambing PE banyak disebabkan oleh Streptococcus sp. Streptococcus sp., dan Corynebacterium $s p$., dapat diisolasi dari mastitis subklinis pada kambing terutama yang berhubungan dengan lantai kandang yang kotor dan kontaminasi dengan lingkungan. Mastitis subklinis karena Streptococcus sp., kebanyakan terjadi dalam waktu yang lama atau kronis (Pisoni et al., 2009). Sementara itu, Koop et al. (2010) menyatakan bahwa Corynebacterium sp., merupakan penyebab mastitis subklinis pada kambing yang menyebabkan penurunan produksi susu setelah Streptococcus sp., dan Staphylococcus spp.

Mastitis subklinis pada kambing PE di Kemiri Kebo, Turi, Sleman disebabkan oleh Pseudomonas aeruginosa sebesar 18\% (Tabel 1). Mastitis subklinis karena Pseudomonas aeruginosa terjadi karena air yang digunakan untuk mencuci ambing terkontaminasi. Selain itu, Pseudomonas aeruginosa banyak ditemukan pada lantai kandang yang basah dan becek. Penelitian Suwito et al. (2013) menunjukkan bahwa air yang digunakan untuk mencuci ambing sebagian besar terkontaminasi Pseudomonas aeruginosa. Hal yang sama juga dilaporkan oleh Heras et al. (1999) bahwa air yang terkontaminasi 
Pseudomonas aeruginosa apabila digunakan untuk mencuci ambing dapat menyebabkan mastitis klinis atau subklinis.

Mastitis subklinis pada kambing PE karena Escherichia coli sangat kecil yaitu 2\% (Tabel 1) Hal tersebut menunjukkan bahwa hanya sedikit sekali kejadian mastitis subklinis karena Escherichia coli. White and Hinckley (1999) dan Contreras et al., (2007) menyatakan bahwa Escherichia coli hanya $1,6 \%$ sebagai penyebab mastitis subklinis pada kambing. Perbedaan hasil tersebut kemungkinan disebabkan oleh tingkat kebersihan yang berbeda antara kandang kambing PE di DIY dengan di luar negeri. Selain itu, peternakan kambing PE di DIY dipelihara secara tradisional oleh peternak kecil sehingga risiko terkontaminasi Escherichia coli lebih besar. Sistem pemerahan di luar negeri sudah banyak mengunakan mesin kemungkinan dapat mengurangi kontaminasi Escherichia coli. Mastitis subklinis karena Escherichia coli disebabkan oleh putting yang bersentuhan dengan lantai setelah diperah, sehingga bakteri mudah masuk putting saat otot spinter masih terbuka. Oleh karena itu, setelah diperah kambing PE segera diberi pakan sehingga tidak diberi kesempatan untuk langsung rebahan di lantai kandang. Mastitis klinis karena Escherichia coli menyebabkan terjadinya toksemia mastitis yang menyebabkan kematian yang didahului dengan gejala dehidrasi, ambruk, koma, dan akhirnya mati (Menzies et al., 2000).

\section{KESIMPULAN}

Mastitis subklinis pada kambing PE lebih dominan disebabkan oleh bakteri Gram positif kelompok kelompok Staphylococcus spp., dan Streptococcus spp., dibandingkan Gram negatif.

\section{DAFTAR PUSTAKA}

Arsenault, J., Dubreuil, P., Higgins, R., and Belanger, D. 2008. Risk factors and impacts of clinical and subclinical mastitis in commercial meat producing sheep flocks in Quebec, Canada. Preventive Veterinary Medicine, 87(3-4), 373-393.

Andresen, L.O. 2005. Production of exfoliative toxin by isolates of Staphylococcus hyicus from different countries. Veterinary Record, 157(13), 376-378.

Bergonier, D., Cremoux, R., Rupp, R., Lagriffoul, R., Lagriffoul, G., and Berthelot, X. 2003. Mastitis of dairy small ruminants. Veterinary Research, 34(5), 689-716.

Contreras, A., Corrales, J.C., Sierra, D., and Marco, J. 1995. Prevalence and aetiology of non clinical intramammary infection in Murciano-Granadia goats. Small Ruminant Research, 17(1), 71-78.

Contreras, A., Luengo, C., Sanchez., A., and Corrales, J.C. 2003. The role of intramamary pathogens in dairy goats. Livestock Production Science, 79(2-3), 273-283.

Contreras, A., Sierra, D., Sanchez, A., Corrales, J.C., Marco, J.C., Paape, M.J., Gonzalo, C. 2007. Mastitis in small ruminants. Small Ruminant Research, 68(1-2), 145-153.

Fthenakis, G.C., and Jones, J.E.T. 1990. The effect of experimentally induced subclinical mastitis on milk yield of ewes and on the growth of lambs. Brasilia Veterinary Journal, 146, 43-49.

Hall, S.M., and Rycroft, A.N. 2007. Causative organisms and somatic cell counts in subclinical intramammary infections in milking 
goats in the UK. Veterinary Record, 160(1), 19-22.

Heras, L., Dominguez, A., Lopez, I., and Garayzabal, J.F.1999. Outbreak of acute ovine mastitis associated with Pseudomonas aeruginosa infection. Veterinary Record, 145(4),111-112.

Koop, G., Werven, T.V., Schuiling, H.J., and Nielen, M. 2010. The effect of subclinical mastitis on milk yield in dairy goat. Journal of Dairy Science, 93(12), 5809-5817.

McDougall, Pankey, W.C., Delaney, Barlow, J., Patricia, A., Murdough and Scruton, D. 2002. Prevalence and incidence of subclinical mastitis in goats and dairy ewes in Vermont USA. Small Ruminant Research, 46(2-3), 115-121.

Menzies, F.D., Mcbride, S.H., Mcdowell, S.W., Mccoy., M.A., Mcconnell, W., and Bell, C. 2000. Clinical and laboratory findings in cases of toxic mastitis in cows in Northern Ireland. Veterinary Record, 147(5), 123-128.

Moroni, P., Pisoni, C., Vimercati, Rinaldi, M., Castigloni, Cremonesi, B.P., and Boetter, P.J. 2005. Staphylococcus aureus isolated from chronically infected dairy goats. Journal of Dairy Science, 88(10), 35003509.

Muda, I., Supriyanto., Kustiningsih, H., Tangkonda E., Heri, dan Indarjulianto, S. 2011. Peran pemerah dalam dalam penyebaran Staphylococcus aureus pada sapi perah. Proceeding. Seminar Nasional PPDH Emerging dan ReEmerging Diseases Tantangan dan Peran Dokter Hewan di Era Global,
3 Desember 2011: 86-93. Fakultas

Kedokteran Hewan Universitas Gadjah Mada, Yogyakarta, Indonesia.

Persson, Y., and Olofsson, I. 2011. Direct and indirect measurement of somatic cell count as indicator of intramammary infection in dairy goats. Acta Veterinaria Scandinavia, 4(53), 15-20.

Pisoni, G., Zadoks, R.N., Vimercati, C., Locatelli, C., Zanoni, M.G., and Moroni, P. 2009. Epidemiological investigation of Streptococcus equi subspecies zooepidermidis involved in clinical mastitis in dairy goats. Journal of Dairy Science, 92(3), 943-951.

Sanchez, A., Contreras, A., and J.C., Corrales. 1999. Parity as a risk factor for caprine subclinical intramammary infection. Small Ruminant Research, 31(3), 197-201.

Sutra, L, and Poutrel, B. 1994. Virulence factor involved in the pathogenesis of bovine intramammary infections due to Staphylococcus aureus. Journal of Medical Microbiology, 40(2), 79-89.

Suwito, W., Wahyuni, A.E.T.H., Nugroho, W.S., dan Sumiarto, B. 2013. Isolasi dan identifikasi bakteria mastitis klinis pada kambing peranakan Ettawah. Jurnal Sain Veteriner, 31(1), 49-54.

Suwito, W., Winarti, E., Kristiyanti, F., Widyastuti, A., and Andriani. 2018. Faktor risiko terhadap total bakteri, Staphylococcus aureus, koliform, dan E. coli pada susu kambing.Jurnal Agritech, 38(1), $39-44$ 
Tomita, M., Bellamy, W., Takase, M., Yamauchi, K., Wakabayashi, H., and Kawase, K. 1991. Potent antibacterial peptides generated by pepsin digestion of bovine lactoferrin. Journal of Dairy Science, 74(12), 4137-4142.

Tong SYC, Davis JS, Eichenberger E, Holland TL, Fowler VG. 2015. Staphylococcus aureus infections, epidemiology, pathophysiology, clinical manifestations, and management. Clin Microbiol Rev, 28, 605-608.

Wegener, H.C., Andresen, L.O., and Hansen, B.V. 1993. Staphylococcus hyicus virulence in relation to exudative epidermitis in pigs. Canadian Journal of Veterinary Research, 57(2): 119-125.

White, E.C., and Hinckly, L.S. 1999. Prevalence of mastitis pathogens in goat milk. Small Ruminant Researh, 33(2), 117-121. 